Spring 2011

\title{
Chinese Papermaking: A Multicultural and Environmental Education Strategy for Pre-K Teachers
}

\author{
Li-Yuan J. Liao \\ Patricia J. Larke \\ Valerie Hill-Jackson
}

Follow this and additional works at: https://digitalscholarship.unlv.edu/jpme

\section{Repository Citation}

Liao, Li-Yuan J.; Larke, Patricia J.; and Hill-Jackson, Valerie (2011) "Chinese Papermaking: A Multicultural and Environmental Education Strategy for Pre-K Teachers," Journal of Praxis in Multicultural Education: Vol. 6: No. 1, Article 8. DOI: 10.9741/2161-2978.1054

Available at: https://digitalscholarship.unlv.edu/jpme/vol6/iss1/8

This Article is protected by copyright and/or related rights. It has been brought to you by Digital Scholarship@UNLV with permission from the rights-holder(s). You are free to use this Article in any way that is permitted by the copyright and related rights legislation that applies to your use. For other uses you need to obtain permission from the rights-holder(s) directly, unless additional rights are indicated by a Creative Commons license in the record and/ or on the work itself.

This Article has been accepted for inclusion in Journal of Praxis in Multicultural Education by an authorized administrator of Digital Scholarship@UNLV. For more information, please contact digitalscholarship@unlv.edu. 


\title{
Chinese Papermaking: A Multicultural and Environmental Education Strategy for Pre-K Teachers
}

\section{Li-Yuan J. Liao, Patricia J. Larke, and Valerie Hill-Jackson}

\begin{abstract}
Many scholars see the urgency of implementing multicultural education (ME) and environmental education (EE) in the primary level (Abdullah, 2009; Bower, 1998; Cohen \& Horm-Wingerd, 1993; Trubowitz, 1995). The scholars also share how hands-on and art approaches fit well in both Multicultural Education and Environmental Education fields (Adams \& Chisholm, 1999; Bower, 1998; Damm, 2006; Seltzer-Kelly, Westwood, \& Peña-Guzman, 2010). Chinese papermaking, an interactive and hands-on exercise in the creation of handmade paper, can be a means of integrating concepts of multiculturalism and sustainability into a young child's education. To address this issue, this study aimed at (a) introducing multicultural education, sustainability, and Chinese papermaking; (b) creating a new model MATCH to synthesize multicultural education and environmental education; (c) showing how papermaking is a culturally enriching activity; and, (d) demonstrating childcentered papermaking activities.
\end{abstract}

An increasingly diverse world population and accelerated urbanization have lead to complex socio-environmental hardships. These challenges require not only sophisticated solutions, but also an educated global populace that understands the necessity of tackling them collectively and holistically. Schools are thus poised to educate their students on both multiculturalism and sustainability; two fields which have divergent and complimentary tenets. While curricula in multicultural education (ME) and environmental education (EE) have been developed for secondary and high school age students, the same cannot be said for primary and Pre-K students. This article proposes a curriculum in multiculturalism and sustainability for Pre-K teachers. We introduce the Chinese papermaking activity as a bridge for connecting $\mathrm{ME}$ and $\mathrm{EE}$.

Li-Yuan J. Liao is a doctoral student in the Department of Teaching, Learning and Culture, Texas A\&M University, College Station, Texas. Her research interests are multicultural education, Montessori early childhood education, and Asian American heritage language maintenance. She is from Taiwan. She can be reached at providence@tamu.edu. Patricia J. Larke is a professor in the Department of Teaching, Learning and Culture, Texas A\&M University, College Station, Texas. Her research fields are multicultural education, educating teachers for diverse classrooms and issues related to teachers of color. She can be reached at plarke@tamu.edu. Valerie Hill-Jackson is a clinical associate professor in the Department of Teaching, Learning and Culture, Texas A\&M University, College Station, Texas. Her research interests are social justice issues and critical cultural issues in education. She can be reached at vhjackson@tamu.edu. 
Papermaking is widely used as a classroom activity in various disciplines - art, history, science, language arts, social studies, and environmental studies (Grambo, 1994; Gruber, 2000; Smith, 1995; Varona \& Beagle-Daresta, 1997; Withroe, 2002). This article explores papermaking through a more interdisciplinary different lens-namely through the lens of multiculturalism and sustainability. To these ends, this article discusses the following: (a) multicultural education, sustainability, and Chinese papermaking; (b) a synthesis of ME and EE; (c) papermaking as a culturally enriching activity; and (d) child-centered papermaking activities.

\section{Chinese Papermaking, Multicultural Education, and Environmental Education}

The Chinese papermaking activity can be viewed as an interdisciplinary curriculum that merges multiculturalism and sustainability. The discussion here illuminates how the papermaking activity can bridge ME with EE.

\section{Multicultural Education}

Multicultural education is a teaching and learning process that helps students develop positive self-esteem, be sensitive to people of different cultural backgrounds, and provide equal opportunities to students so that they may learn to their fullest potential (Banks, 2006; National Association for Multicultural Education [NAME], 2003). ME can play a pivotal role in a child's early learning (De Melendez \& Beck, 2007; York, 1991). ME can "permeate school curriculum and instructional strategies as well as the interactions among teachers, students, and families and the very way that schools conceptualize the nature of teaching and learning" (Nieto \& Bode, 2008, p. 44). According to Morgan (2000), "cross-cultural considerations can be a major influence in the successful understanding of educational and instructional concepts" (p.491) not only because we live in a pluralistic society, but also because incorporating culture into teaching and learning can make the process more efficient, colorful, and creative. In this way, ME should not be separated out from existing curriculum; teachers need to work to integrate multiculturalism into existing subject- and skill-based curricula (Gay, 2004). This incorporation of crosscultural perspectives and cultural awareness into subject- and skill-based curricula has been discussed and promoted by many multiculturalism scholars (Banks \& Banks, 2007; Davidman \& Davidman, 2001; De Ramirez, 2009; Gay, 2004; Pang, 2001; York, 1991).

In our case, the papermaking activities we address deal specifically with Chinese culture. In contemporary society one is well aware of just how 
many consumer goods are produced in China; however, few know that one of our most fundamental consumer products, paper, was invented by the Chinese. Indeed it is one of the most remarkable inventions to come out of China, and its influence on the world and communication goes without saying. Luoma (1997) writes, "...[H]umans had been searching for the ideal surface on which to record ideas... [P] apermaking ...set the stage for the first information revolution" (p.98). At the 2008 Olympic Opening Ceremony in Beijing, performances focused on the themes of Chinese history, invention, culture, art, and China's diverse ethnic groups. One of the performances incorporated the ancient artifacts of Chinese paper, ink, and brush. Onto the stage was unfurled a white paper scroll, on which entered dancers clothed in black. The dancers had hidden inkdipped brushes in their hands and while dancing atop the paper scroll left traces of ink on top of it. The performance encapsulated the art of Chinese water-color painting and its Four Treasures: paper, brush, ink stick, and ink stone.

These Treasures can equally be used in the classroom setting as a means of broadening cultural knowledge and understanding amongst students. The hands-on approach provides students with a tactile, experiential approach to fulfill the following objectives of multicultural education: "(a) building mutual understanding among various racial and cultural groups; (b) building a sense of appreciation for different cultures; and (c) rendering curricula relevant to the experiences, cultural traditions, and historical contributions of the nation's diverse population" (Webb, 1990).

\section{Environmental Education}

A 1995 news article reported that each individual in the U.S. used an average of 731 pounds of paper annually, which was more than double the amount used the decade before, and more than the average used in any other nation (Luoma, 1997). Indeed a serious case could be made for paper conservation in the U.S., and, perhaps more importantly, a case for teaching our students the process behind the paper they consume in the first place. Teaching students the process of papermaking introduces them to ideas of resource consumption, reusing, and recycling, and is a well-documented EE activity (Cowens, 2003; De Prenger, 1987; Fetters, 2001; Galus, 2002; Grambo, 1994; Gruber, 2000; Malam, 2006; Smith, 1995; Withroe, 2002). "Environmental education" is defined as (IUCN, 1970):

the process of recognizing values and clarifying concepts in order to develop skills and attitudes necessary to understand and appreciate the interrelatedness among man, his culture, and his biophysical surroundings. Environmental education also entails practice in decision-making and self-formulation of a 
code of behavior about issues concerning environmental quality. (as cited in Palmer 1998, p. 7)

The current updated definition from California Department of Education (2010) defines environmental education as:

the teaching about the natural and built environment which provides a real-world context for learning by linking the classroom to the students' community. Students are engaged in hands-on, active learning that increases their knowledge and awareness about the environment.

Sustainability is at the essence of all EE activities. An online definition of sustainability yields, "a method of harvesting or using a resource so that the resource is not depleted or permanently damaged, or relating to a lifestyle involving the use of sustainable methods" (Sustainable, 2009). In Education for Sustainability as a Frame of Mind, Bonnett (2002) makes the case that the definition of sustainability is not human- or nature-centered, but more so about raising a critical and authentic consciousness of care for our environment. Bonnett (2002) goes on to argue that sustainability must inspire in individuals a positive change in attitude towards the environment as well as towards their own identities. The main focus of sustainability efforts has been to change environmental attitudes and behavior through increasing environmental knowledge (Pooley \& O’Connor, 2000). According to Stevenson (1987), the goal of environmental education is:

the intellectual task of critical appraisal of environmental (and political) situations and the formulation of the moral code concerning such issues, as well as the development of a commitment to act on one's values by providing opportunities to participate actively in environmental education." (Stevenson, 1987, as cited in Palmer, 1998, p. 94)

We believe that these concepts are essential to the papermaking activities because papermaking is the initiative to promote environmental education.

\section{The Synthesis of Multicultural and Environmental Education}

One obstacle that remains in unpacking the themes of $\mathrm{ME}$ and $\mathrm{EE}$ is articulating the relationship between the two traditions. The authors, therefore, have created a conceptual framework by which to identify the features in ME and EE that are parallel and distinct for each field (see Figure 1). In this new model, we use the acronym MATCH, which represents the five key ideas that ME and EE share: morality, action, tolerance, culture, and harmony. 
ME is a unique field because it deals with issues of equity for underserved populations in the U.S. By contrast, EE is primarily concerned with humans' interaction with their environment. However, there are five key features in which these two seemingly different fields share common traits. Each of the five key components are discussed below.

Morality - In ME, morality takes on a huge significance as it relates to the ability of persons to conform to moral behavior as set by their own cultural arrangements and not to a set of pre-determined principles of one dominant group (Lynch, 1989; Wright \& LaBar, 1984). Morality in this sense is the expression of what is deemed good or bad based on a specific cultural group's version of truth. Likewise, the field of EE asserts that moral value lies in the Figure 1

The model of MATCH in ME and EE: Morality, Action, Tolerance, Culture, and Harmony

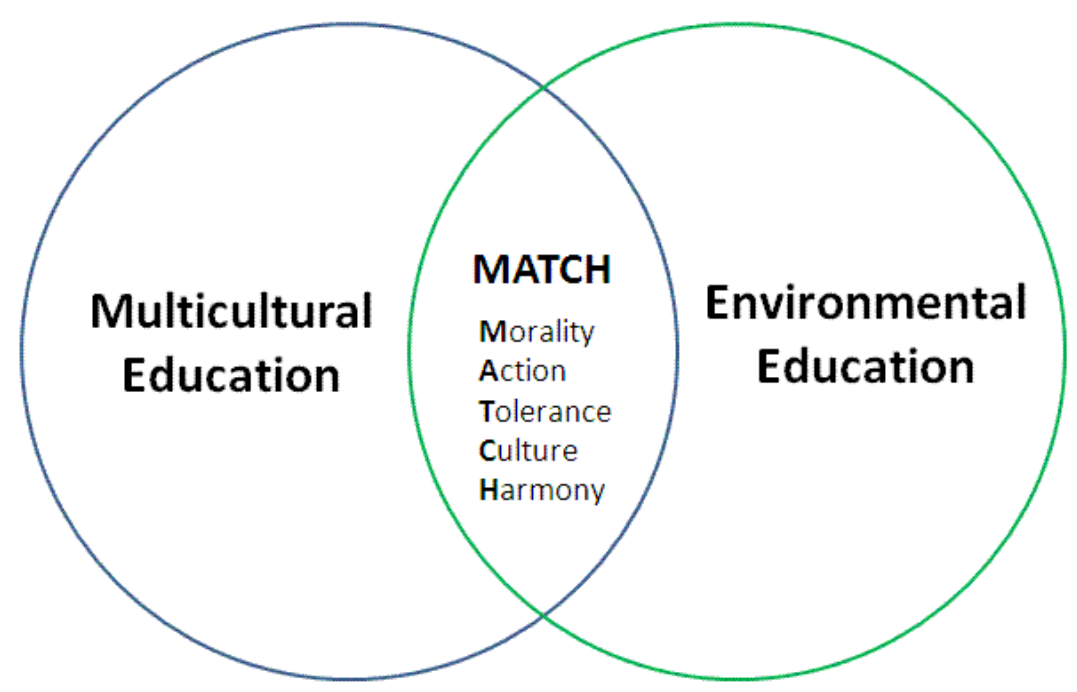

ability to bring sustainability itself into question (Des Jardins, 2005). Morality for both fields entails a search for multiple arrangements of truth with the recognition and affirmation of the multiple perspectives or versions of truth.

Action - In ME and EE, there are several levels at which the educator can integrate these themes into the curriculum. For both fields the primary goal is for the curriculum to inspire students to shift from passive to active participants. Students and educators are encouraged to be a part of a moving 
curriculum that extends beyond the textbook or classroom environment (Banks, 2008; Corcoran, 1999; Vavrus, 2002).

Tolerance - In a pluralistic society, it becomes necessary to recognize and respect the beliefs or practices of others. Essentially, tolerance is a principled commitment for both fields in which we all empathize with and support each other and the environment, out of respect and deference (De Melendez \& Beck, 2009; Filippaki \& Kalaitsidaki, 2011).

Culture - Culture includes a group's operating paradigms and programs for survival (Marshall, 2002). According to Gollnick and Chinn (1986), culture is the blueprint for the way a person thinks, feels, and behaves in society. Culture is both tangible and intangible. It is a political phenomenon that manifests itself amongst educators, students, schools, and society. The normative culture of mainstream society tends to place minimal intrinsic value on the natural environment. In EE, we value culture as a means of assessing how certain groups value or disregard the environment (Smith \& Williams, 1999). It is a way to elicit a shared consciousness of care for the environment. In ME and $\mathrm{EE}$ the focus is to move away from normative curricula and towards multicultural considerations. The fields of ME and EE recognize culture as a means of understanding the way different groups interpret their environment and as a vehicle for transmitting their culture values.

Harmony - Harmony is a condition in which everything - including the inner and outer world - works together effectively. In ME, harmony is expressed through multiple groups interacting via cultural understanding, claiming no cultural elitism over each other, and living democratically (Vogt, 1997). Similarly, EE recognizes harmony as a solidarity amongst people working together to protect the world's natural resources (Kawagley \& Barnhardt, 1999). Both fields express a global understanding of community and promote the link between unity and stewardship.

The five key features of MATCH (morality, action, tolerance, culture, and harmony) can be salient and compelling features of any Pre-K curriculum. Particularly, papermaking activities in Pre-K curriculum "match" the essential criteria of both ME and EE that are mentioned above. Papermaking activities truly represent a working model of MATCH. In papermaking activities, students are instilled a positive perspective of morality by the awareness of multiculturalism and sustainability. The hands-on papermaking activities provide a direct action to our environment within both multicultural and sustainability contexts. Tolerance and Chinese culture are introduced in a harmony papermaking process. For the Pre-K audience, hands-on papermaking activities provide a powerful means for students to become engaged in the meaning-making development for both ME and EE.

\section{Using Culturally Appropriate Materials as Teaching Tools}


Using particular materials as teaching tools in the classroom helps bridge the gap between teacher instruction and student learning. Spelleri (2002) suggests that the new concept depends on the "scaffolding" of a meaningful context. She believes that a rich and relevant context can highlight the relationship between the materials and the learner's life. In other words, the materials facilitate the transfer of the learners' existing knowledge to their life experiences. Dewey (2005) stresses that "[s]ufficient direct experience is even more a matter of quality; it must be of a sort to connect readily and fruitfully with the symbolic material of instruction" (p. 273).

A culturally meaningful curriculum has a significant relationship with culturally appropriate materials in a classroom setting. Certain multicultural materials can help teachers create rich and exciting multicultural curricula (Grant \& Sleeter, 2009). Culturally appropriate material can not only make abstract concepts more concrete, but it can also serve as a fertilizer, enriching the land of multicultural education. Especially for younger children, the particular arrangement of the classroom and the materials used help to increase their engagement with the particular curriculum (York, 1991). Davidman \& Davidman (2001) encourage teachers to create a multicultural classroom setting, through classroom layout and visual materials, so that students are immersed in the multicultural learning experience.

\section{Child-Centeredness and Papermaking Activities}

Banks, Darling-Hammond, and Greene (1992) suggest that "schools must become learner-centered to meet the needs of today's diverse students" (p.3). Bransford, Brown, and Cocking (1999) note that learner-centered environments are produced when teachers are aware that learners construct their own meanings through the beliefs, understandings, and cultural practices they bring to the classroom. It is critical that teachers understand the personal experiences of their students, so as to make the curriculum culturally meaningful and the instruction effective (Pang, 2001).

Every child is unique and has an inner function. By inner function, we mean that children have their own inner guidance for perfect adaptation to their environment (Montessori, 1982). For the child to be engaged with and enjoy his/her schoolwork, it is crucial to tailor curriculum to his/her interests. We believe that each child has his/her own learning style and pace at which they process information. Children develop important cognitive and social skills in their learning environment (Crain, 2000). In this way, a teacher is a construction worker who builds the scaffolding to help children connect the pieces in that development process. It is important for teachers to provide children with smooth transitions to the next level of learning. Dewey (2005) addresses the 
important concept of learning by doing. He points out that, "on the active hand, experience is trying - a meaning which is made explicit in the connected term experiment" (p.163) corresponding to "when learning involves hands-on experiences, students are apt to learn more" (Larke, 1988, p. 16). Papermaking is a child-centered activity, which focuses on a child's hands-on learning experiences. The procedures of papermaking are multifarious and need clear guidelines. Students need to follow the guidelines step by step in order to implement the whole process of papermaking. In this way, the "...experience involves a connection of doing or trying with something which is undergone in consequence" (Dewey, 2005, p.177). Pre-papermaking activities are designed for students to familiarize themselves with the sequence of the papermaking process. The following two activities will help students develop a sense of order in the papermaking process.

\section{Papermaking Activities}

The pre-papermaking activities are designed for children to familiarize themselves with the sequence of the papermaking process. These activities include papermaking flash cards, papermaking sequence matching cards, papermaking booklet, and papermaking song.

Papermaking Flash Cards. A set of cards with a picture on one side and the corresponding vocabulary on the other (see Figure 2) assists children to be able to understand an abstract concept (recycling), the name of material (deckle), and semi-finished product (pulp).

Figure 2

A set of flash cards as an assistant material to help children to understand certain environmentally abstract concepts

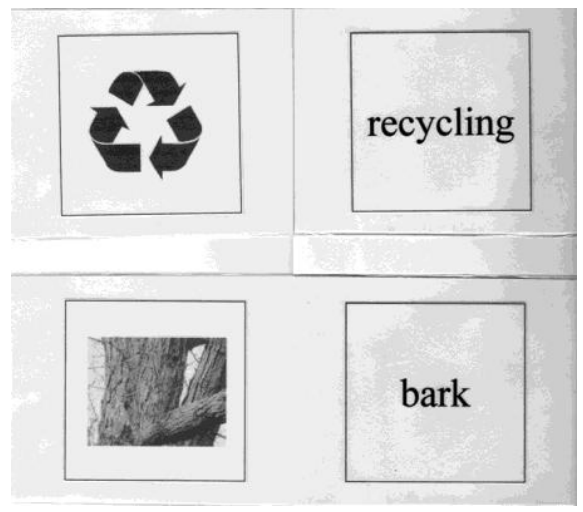


Papermaking Sequence - Matching Cards: Here are provided a set of cards on the sequencing of papermaking and a sheet on papermaking procedures (see Figure 3). These two laminated sets of sheets and cards are exactly the same and contain numerals, descriptions, and pictures. Let the children match the direction sheet and sequence cards to enhance their familiarity with the papermaking process.

Figure 3

A set of sequence cards with a corresponding procedure sheet on papermaking

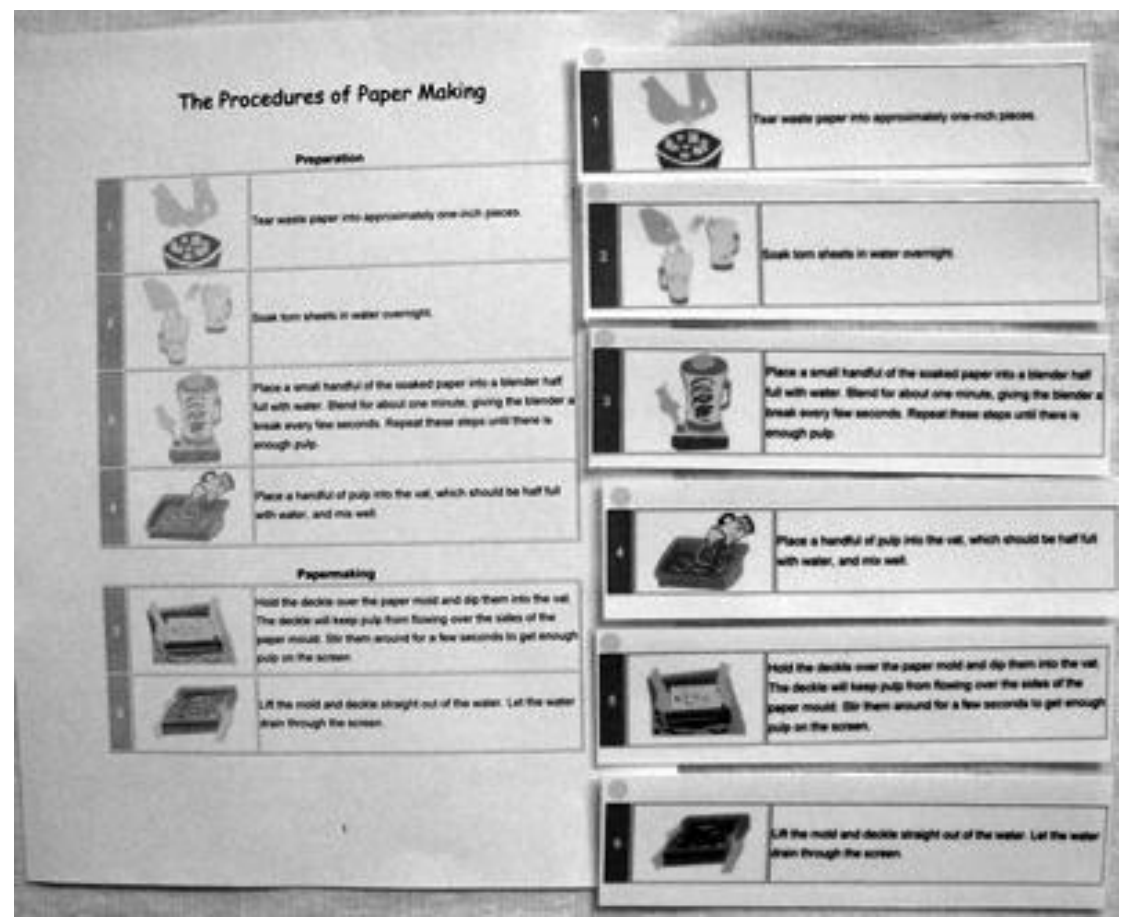

Papermaking Booklet: Here is provided a paper booklet (see Figure 4) with pictures on papermaking procedures. Children can both color in the drawings and number the pages 1-12 within the circles provided. This preparatory activity is designed for children to get involved in the process of making their own paper and also for them to practice number order. 
Figure 4

My Papermaking Booklet familiarizes children with the papermaking process.

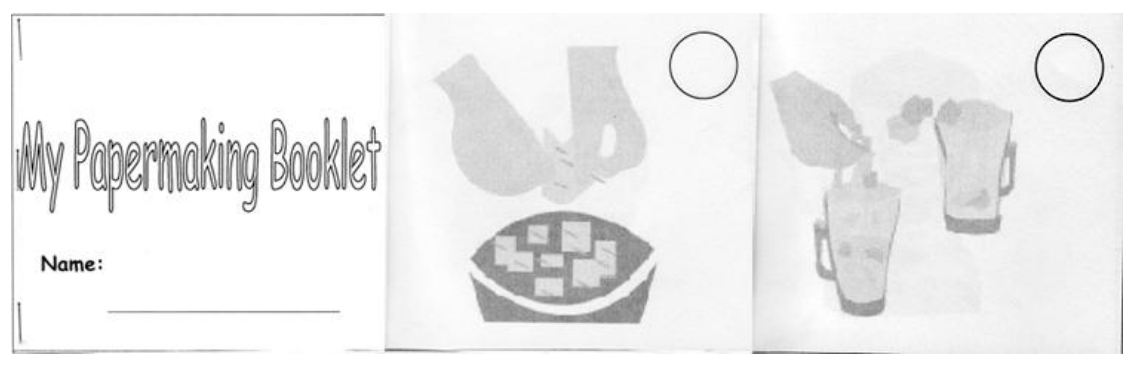

Papermaking Song: Show the Sesame Street (n.d.) video entitled "Papermaking Class" before starting the papermaking activity. The video contains a country song sung by Jerry Nelson that captures the process of papermaking and offers a holistic picture of the process. Teachers who wish to use materials other than this video should feel free to do so.

The following papermaking activities are designed so that teachers may build up children's ME and EE competencies.

\section{Papermaking: Developing a Broad Range of Educational Competencies}

The papermaking project is an active initiative in multiculturalism and sustainability. Research on both ME (Terenzini, Cabrera, Colbeck, Bjorklund, \& Parente, 2001) and EE (Rickinson, 2001) has shown that curriculum that engages students' knowledge, attitudes, and actions can produce positive outcomes. The following activities are strategies for teachers to transform concepts of multiculturalism and sustainability into concrete activities.

\section{Enrichment Activities to Incorporate Multicultural Education}

As an additional feature to this article, we provided some mini-activity outlines with accompanying materials for teachers to become aware of resources that are culturally meaningful. A discussion on cultural differences is evident in the Chinese papermaking activity and in several related mini-activities that highly related to this exercise. For instance, an accompanying storybook related to Chinese history and culture can provide an alternative, non-Western narrative to the papermaking process. Using Chinese brushes and ink, which allow for 
drawing opportunities on the newly made paper, can be another experience to engage children in the ancient Chinese drawing and writing atmosphere. The sum of all of these culturally relevant parts introduced below will have a profound effect on a child's Chinese cultural experiences.

Storybook Reading: A picture book entitled The Story of Paper (Compestine \& Xuan, 2003) recounts the history of the invention of paper through a fictionalized story. It offers a general idea of how people lived in ancient China. The look and feel of the book is distinctly Chinese, including quintessentially Chinese illustrations and engravings. As the story is fictionalized, teachers can use this book as a precursor to the full history of Chinese papermaking.

History of Chinese Papermaking: In this part teachers provide a brief overview of how paper was invented in ancient China. The invention of paper has obviously played a significant role in the evolution of human civilization, as suddenly humans could document and retain information. The story goes that in approximately 150 A.D. a Chinese official named Tsai Lun used a combination of bark, bamboo, recycled fishing nets, and hemp to make the first paper (Luoma, 1997).

Chinese Character Writing Practice: Materials for the writing of Chinese characters can introduce children to different methods of writing. Many Chinese characters are derived from pictographs, which is completely different from the English writing system.

Figure 5

Materials for the writing of Chinese characters offer children the opportunity to explore different methods of writing.

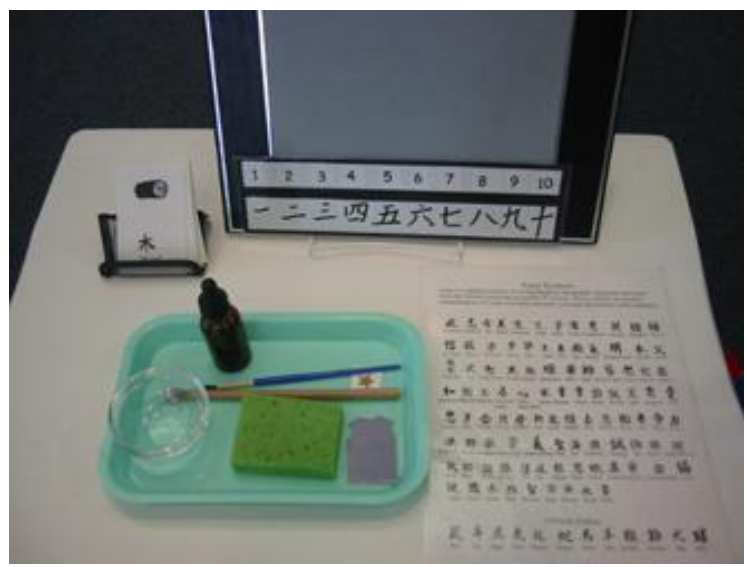


Drawing with the Chinese Brush. Prepare Chinese ink and brushes, which students can use to draw on their handmade paper. Chinese ink and brushes work perfectly with the texture of handmade paper, which is quite similar to the ancient Chinese Shan paper used by ancient Chinese writers. Introducing children to Chinese writing tools can be used as a window into Chinese culture.

Figure 6

A child's drawing on handmade paper with Chinese brush and ink

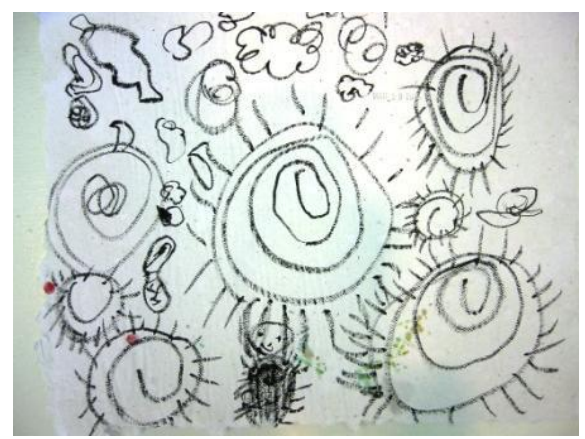

Figure 7

A drawing by two children that includes an attempt at writing some Chinese characters ${ }^{1}$.

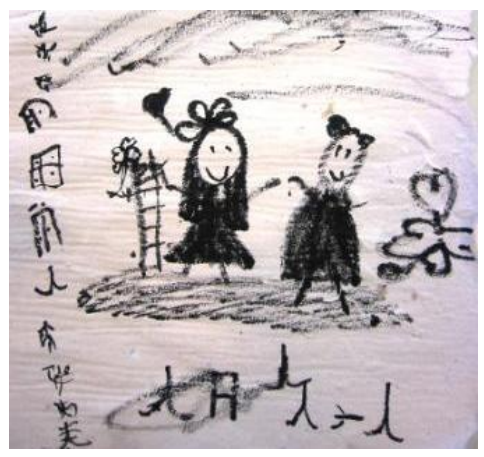

\footnotetext{
${ }^{1}$ The two female European American children who did not learn Chinese characters, spontaneously wrote some words on their hand-made paper. They said they were writing Chinese words. Although they did not write them exactly, this evidence shows the Chinese character writing practice did give them an image of how Chinese characters might possibly look.
} 


\section{Enrichment Activities to Incorporate Environmental Education}

Environmental education-related activities will introduce children to paper types, environmental association, natural resource substantiality, and paper recycling.

Understanding Paper Types: This is designed to give children sensory experience with different kinds of paper. Provide a variety of paper types for children to touch, look at, and feel. Teachers can make a booklet that contains various kinds of paper cut to the same size. Allow the children to discover differences in appearance, color, thickness, and texture. Malam (2006) suggests laying out different types of paper, such as tissue paper, newspaper, wallpaper, and so on, and letting the children name them and describe the different uses for each kind of paper.

Making Associations: Ask the children questions such as, "What things are made of paper?" "What activities have we done in class that have used paper?" Such questions can encourage children to make connections between paper and the environment.

Pre-invention of Paper: Before the papermaking activity, pose the question: "Before paper was invented, what did people write on?" Let the children think for a while. Then explain to them that the Egyptians used to write on papyrus; the Greeks on animal skin; and the ancient Chinese on bare earth, turtle shells, bones, bamboo, or - if they were wealthy - on silk (Luoma, 1997). This provides the children with a global view of how ancient people from different places used to record information. Additionally it introduces the students to the diverse array of natural resources and materials ancient people used for writing. Use this discussion as an opportunity for the children to think about natural resources and how they can be used sustainably.

The Concept of Paper Recycling: Pose the questions: "What is recycling?" and "Why is recycling paper important?" Explain to them that paper is in part made from the part of the tree called bark. Pass a piece of bark around for the children to look at and touch. Explain that trees are important in part because they produce oxygen, which we need to breathe. Then lead them to a recycling bin and find examples of paper that has barely been written on versus paper that has been written on both sides. Explain that both sides of a sheet of paper can be used. "If we are not satisfied with what we have drawn, we can turn the paper over and draw on the other side." Explain how this is one very easy way to reduce waste and recycle.

Appreciating Nature Resource: Many of the suggested materials can simply be found in nature, such as the peeled off bark from the tree. Letting children feel and touch the bark can help them become acquainted with the manufacturing raw materials that go into making paper. Teachers may also 
provide falling leaves and flower petals, which the children can then put in the pulp to make their unique recycling paper.

\section{Conclusion}

This article is framed under the theme of sustainability (Bonnett, 2002), and is simultaneously tied in to a multicultural conversation intended to empower Pre$\mathrm{K}$ educators. The discussions in this study have sought to include (a) multicultural education, sustainability, and Chinese papermaking; (b) the synthesis of multicultural education and environmental education; (c) representing papermaking as a culturally enriching activity; and (d) childcentered papermaking activities. The teaching of both $\mathrm{ME}$ and EE is guided by a newly conceived conceptual model, MATCH, which contains principles of morality, action, tolerance, culture, and harmony. These principles provide some tangible ideas for Pre-K teachers on creating new learning opportunities, and on designing interdisciplinary strategies that enrich a child's awareness of multicultural perspectives, sustainability, and creative artwork. In this action research endeavor, we have personally found the teaching of papermaking to be truly engaging for students and teachers alike. The implementation of multiculturalism and sustainability through Chinese papermaking into the U.S. educational system is a true means of encouraging our students to be global citizens because "now is the time for the early childhood educators to catch up with community concerns about environmental [and multicultural] issues and to take a leadership role in an area in which we have the potential to make a difference" (Davis, 1998, p.143).

\section{References}

Abdullah, A.C. (2009). Multicultural education in early childhood: Issues and challenges. Journal of Educational Cooperation in Education, 12(1), 159-175.

Adams, E., \& Chisholm, T. (1999). Art, design and environment: A programme for teacher education. Journal of Art and Design Education, 18, 337-344.

Banks, J., Darling-Hammond, L., \& Greene, M. (1992). Building learner-centered schools: Three perspectives. New York: Teachers College, Columbia University.

Banks, J. (2006). Cultural diversity and education: Foundations, curriculum, and teaching ( $5^{\text {th }}$ ed.). MA: Pearson Education, Inc.

Banks, J., \& Banks, C. (Eds.). (2007). Multicultural education: Issues and perspectives ( $6^{\text {th }}$ ed.). New York: John Wiley.

Banks, J. (2008). An introduction to multicultural education ( $4^{\text {th }}$ ed.). Boston, MA: Pearson Education, Inc. 
Bonnett, M. (2002). Education for sustainability as a frame of mind. Environmental Education Research, 8(1), 9-20.

Bower, L. (1998). Why teach environmental education in early childhood? Every Child, 4(4), 16-17.

Bransford, J., Brown, A., \& Cocking, R. (Eds.) (1999). How people learn: Brain, mind, experience, and school. Washington, D.C.: The National Academies Press.

California Department of Education (2010). Environmental Education/Science Definitions. Received from http://www.cde.ca.gov/pd/ca/sc/oeedefinitions.asp

Cohen, S., \& Horm-Wingerd, D. (1993). Children and the environment: Ecological awareness among preschool children. Environment and Behavior, 25(1), 103120.

Compestine, Y., \& Xuan, Y. (2003). The story of paper. New York: Holiday House, Inc.

Corcoran, P. B. (1999). Environmental autobiography in undergraduate education studies. In G.A. Smith \& D. Williams (Eds.), Ecological education in action: On weaving education, culture, and the environment (pp. 179-188). New York: SUNY Press.

Cowens, J. (2003). No paper? No problem! Teaching K-8, 34(1), 50\&52.

Crain, W. (2000). Theories of development: Concept and applications. Upper Saddle River, New Jersey: Prentice-Hall, Inc.

Davidman, L., \& Davidman, P. (2001). Teaching with a multicultural perspective: A practical guide ( $3^{\text {rd }}$ ed.). New York, NY: Addison-Wesley Educational Publishers Inc.

Davis, J.M. (1998). Young children, environmental education and the future. In: N. Graves (Ed.), Education and the environment (pp.141-154). London, UK: World Education Fellowship.

Des Jardins, J.R. (2005). Scientific ecology and ecological ethnics: The challenges of drawing ethnical conclusions from scientific facts. In Johnson, E.A. \& Mappin, M.J. (Eds.), Environmental education and advocacy: Changing perspectives of ecology and education (pp. 31-49). Cambridge, MA: Cambridge University Press.

De Melendez, W.R., \& Beck, V. (2007). Teaching young children in multicultural classrooms: Issues, concepts, and strategies. ( $2^{\text {nd }}$ ed.). Albany, NY: Delmar Publishers.

De Prenger, K. (February, 1987). Elementary papermaking. School Arts, 86, 19-20.

De Ramirez, L.L. (2009). Take action: Lesson plans for the multicultural education. New Jersey: Pearson Education, Inc.

Dewey, J. (2005). Democracy and education: An introduction to the philosophy of education. New York: Cosimo, Inc.

Fetters, M.K. (2001). Papermaking as a science activity, Science Activities, 37(3), 26-34.

Filippaki, A., \& Kalaitsidaki, M. (2011). The use of environmental education as a tool for inclusion education. In E. Kourkoutas \& F. Erkman (Eds.), Interpersonal acceptance-rejection in special educational and clinical contexts (pp.143-150). Boca Raton, FL: Brown Walker Press.

Galus, P. (2002). Recycling the paper trail. Science Scope, 25(7), 30-33.

Gay, G. (2004). The importance of multicultural education. Educational Leadership, 61, 30-35. 
Gollnick, D., \& Chinn, P.C. (1986). Multicultural education in a pluralistic society. $\left(2^{\text {nd }}\right.$ ed.). Columbus, $\mathrm{OH}$ : Charles E. Merrill Publishing Company.

Grambo, G. (May, 1994). The art of papermaking, Science Scope, 17(8), 36.

Grant, C.A., \& Sleeter, C.E. (2009). Turning on learning: Five approaches for multicultural teaching plans for race, class, gender, and disability. Hoboken, NJ: John Wiley \& Sons, Inc.

Gruber, D. (2000). Really basic papermaking, Arts \& Activities, 128(2), 34-35, 54.

IUCN (1970). Final report - International working meeting on environmental education in the school curriculum. Gland, Switzerland: International Union for the Conservation of Nature.

Kawagley, A.O., \& Barnhardt, R. (1999). Education indigenous to place: Western science meets native reality. In G. Smith \& D. Williams (Eds.), Ecological education in action: On weaving education, culture, and the environment (pp. 117-142). New York: SUNY Press.

Larke, P.J. (1988). Geometric extravaganza: Spicing up geometry. Arithmetic Teacher, $36(1), 12-16$.

Luoma, J.R. (1997). The magic of paper, National Geographic, 191, 88-109.

Lynch, J. (1989). Multicultural education in a global society. New York, NY: Falmer Press.

Malam, J. (2006). Making home-made paper, Child Education, 83(2), 20-21.

Marshall, P.L. (2002). Cultural diversity in our schools. Belmont, CA: Wadsworth/Thomson Learning.

Montessori, M. (1982). Secret of childhood. New York: Ballantine Books.

Morgan, K. (2000). Cross-cultural considerations for simulation-based learning environments, Simulation \& Gaming, 31(4), 491-508.

NAME (2003). Retrieved from http://www.nameorg.org/resolutions/definition.html

Nieto, S., \& Bode, P. (2008). Affirming diversity: The sociopolitical context of multicultural education ( $5^{\text {th }}$ ed.). Boston, MA: Pearson Education, Inc.

Pang, V.O. (2001). Multicultural education: A caring-centered, reflective approach. New York: McGraw Hill Higher Education.

Palmer, J. (1998). Environmental education in the $21^{\text {st }}$ century: Theory, practice, progress and promise. New York: Routledge.

Pooley, J.A., \& O'Connor, M. (2000). Environmental education and attitudes: Emotions and beliefs are what is needed. Environment and Behavior, 32(5), 711-723.

Prince, H. (1999). Experiential environmental education for primary aged children. In P. Higgins \& B. Humberstone (Eds), Outdoor education and experiential learning in the $U K$ (pp. 23-29). UK: Institute for Outdoor Learning.

Rickinson, M. (2001). Learners and learning in environmental education: A critical review of the evidence, Environmental Education Research, 7(3), 207-320.

Sesame Street (Producer), \& Nelson, J. (Singer). (n.d.). Papermaking class (Season 28, Episode 148), Retrieved from http://www.sesamestreet.org/video_player? p_p_lifecycle=0\&p_p_id=videoPlayer_WAR_sesameportlets4369\&p_p_uid=2 cd0793b-155b-11dd-a62f-919b98326687

Seltzer-Kelly, D., Westwood, S.J., \& Peña-Guzman, D.M. (2010). Deweyan multicultural democracy, Rortian solidarity, and the popular arts: Krumping into presence. Studies in Philosophy and Education, 29(5), 441-457. 
Smith, G. (1995). Teaching hand papermaking: A classroom guide. Cedar Rapids, IA: Zpaperpress.

Smith, G.A., \& Williams, D.R. (1999). Introduction: Re-engaging culture and ecology. In G.A. Smith \& D. Williams (Eds.), Ecological education in action: On weaving education, culture, and the environment (pp. 179-188). New York: SUNY Press.

Spelleri, M. (2002, March/April). From lesson to life: Authentic materials bridge the gap, ESL Magazine, 5(2), 16-18.

Stevenson, R. (1987). Schooling and environmental education: Contradictions in purpose and practice. In I. Robottom (Ed.) Environmental education: practice and possibility (pp. 69-82). Geelong, Victoria: Deakin University Press.

Sustainable. (2009). In Merriam-Webster Online Dictionary. Retrieved from http://www.merriam-webster.com/dictionary/sustainable

Terenzini, P., Cabrera, A., Colbeck, C., Bjorklund, S., \& Parente, J. (2001). Racial and ethnic diversity in the classroom: Does it promote student learning? The Journal of Higher Education, 72(5), 509-531.

Trubowitz, J. (1995). A multicultural education experience: The importance of process. Urban Education, 30(3), 306-316.

Varona, A., \& Beagle-Daresta, P. (1997). The art and science of making paper. Science Teacher, 64(5), 42-44.

Vavrus, M.J. (2002). Transforming the multicultural education of teachers: Theory, research, and practice. New York: Teachers College Press.

Vogt, W.P. (1997). Tolerance and Education: Learning to live with diversity and difference. Thoustand Oaks, CA: Sage Publications, Inc.

Webb, M. (1990). Multicultural education in elementary and secondary schools, ERIC Digest, 67, (ERIC Document Reproduction Service No. ED327613).

Withroe, J. (2002). Papermaking and poetry, Arts Edge, (ERIC Document Reproduction Service No. ED477981).

Wright, I., \& LaBar, C. (1984). Multiculturalism and morality. In S. Shapson \& V. D'Oyley (Eds.), Bilingual and multicultural education: Canadian perspectives. (pp. 112-129). Philadelphia, PA: Multilingual Matters.

York, S. (1991). Roots \& wings: Affirming culture in early childhood programs. St. Paul, MN: Redleaf Press.

\section{Suggested Resources Available for Teachers}

Blick Art Materials. (2009). Lesson plans by discipline: Book and papermaking. http://www.dickblick.com/lesson-plans/creative-paper-making/

Grummer, A.E. (2011). Trash-to-treasure papermaking. North Adams, MA: Storey Publishing. 
Herberholz, B. (2004). Classroom papermaking: Handmade papers from recycled and plant fibers, Tucson, AZ: Nash/Renfrow Production.

National Gardening Association. (2002). Making paper. http://www.kidsgardening.com/growingideas/projects/nov02/pg1.html

Robert C. Williams Paper Museum (2009). www.ipst.gatech.edu/amp 